\title{
Profil Kebutuhan Pengasuhan Anak pada Pasangan Muda
}

\author{
Nurul Hidayah ${ }^{*}$, Nissa Tarnoto $^{2}$, Ega Asnatasia Maharani ${ }^{3}$ \\ 1,2Fakultas Psikologi Universitas Ahmad Dahlan \\ ${ }^{3}$ Fakultas Keguruan dan Ilmu Pendidikan Universitas Ahmad Dahlan \\ e-mail : "nurul.hidayah@psy.uad.ac.id
}

\begin{abstract}
Nowadays, there are many married couples in Indonesia who have not unable to nurture their children effectively. This study aims at developing curriculum on child nurturing for young couples to optimize their children's growth. The implementation of the research will be done in multiyear. In the first year, the focus will be on the needs assessment on young couples related to some important issues. The subjects of the research will be 132 parents aged up to 30 years old who have been married for up to 5 years. The place of the research will be in four districts in DIY with focus group discussion (FGD) method as the main instrument. The FGD will be applied with Rapid Rural Appraisal (RRA) method. Data analysis using thematic analysis. The results showed that the profile of the young couple's needs on parenting consisted of five aspects: (1) the nurturing dimension consisting of physical, cognitive, and affective dimensions; (2) self-centered, child-centered, and parent-child parenting goals; (3) forms of care in the form of demand, control, response, and acceptance; (4) framework which includes nuclear family and extended family; and (5) how to overcome both internal and external parenting barriers.
\end{abstract}

Keywords: Nurturing, Young Couple, Parenting Problem

\begin{abstract}
Abstrak. Saat ini, di Indonesia, banyak orangtua belum memiliki kemampuan membentuk pengasuhan anak efektif. Penelitian ini bertujuan menyusun kurikulum pengasuhan anak bagi pasangan muda agar peran orangtua dalam tumbuh kembang anak menjadi optimal. Pelaksanaan penelitian berjalan secara multiyears, dengan fokus tahun pertama pada need assessment pasangan muda terkait isu-isu parenting. Subjek penelitian adalah 132 orangtua berusia maksimal 30 tahun atau telah menikah maksimal 5 tahun. Lokasi pengambilan data di empat kabupaten DIY dengan metode focus group discussion (FGD) sebagai instrumen utama. FGD ini diterapkan dengan metode RRA (Rapid Rural Appraisal). Analisis data menggunakan analisis tematik. Hasil penelitian menunjukkan bahwa profil kebutuhan pasangan muda tentang pengasuhan anak terdiri dari lima aspek: (1) dimensi pengasuhan anak yang terdiri dari dimensi fisik, kognitif, dan afektif; (2) tujuan pengasuhan anak yang berfokus pada diri sendiri, anak, dan hubungan orangtua-anak; (3) bentuk-bentuk pengasuhan anak berupa tuntutan, kontrol, respon, dan penerimaan; (4) framework yang meliputi nuclear family dan extended family; serta (5) cara mengatasi hambatan pengasuhan anak baik internal maupun eksternal.
\end{abstract}

Kata Kunci: Pengasuhan Anak Anak, Pasangan Muda, Masalah Pengasuhan Anak

Dari tahun ke tahun fenomena meningkatnya kenakalan remaja semakin meningkat, hal ini bisa disebabkan oleh beberapa faktor salah satunya adalah faktor keluarga (BPS,2010). Unayah dan Sabarisman (2015) menyatakan bahwa meningkatnya tindakan-tindakan kenakalan remaja saat ini salah satu 
penyebabnya adalah pengasuhan anak orang tua yang kurang tepat dan kesibukan orang tua dalam bekerja. Pengasuhan anak yang buruk atau kurang tepat juga menyebabkan anak menjadi pribadi yang memiliki kontrol diri rendah atau low self control dan sikap yang agresif (Unnever, Cullen \& Agnew, 2006), dan semua itu akan berdampak pada pribadi anak tersebut hingga dewasa. Hal ini juga didukung dengan beberapa tokoh yang menyatakan bahwa pengasuhan memiliki korelasi dengan perkembangan anak selanjutnya. Pengasuhan juga memiliki korelasi dengan kemampuan akademik anak (Alsheikh, Parameswaran, dan Elhoweris, 2010 ; Turner, Chandler, dan Heffler, 2009), kemampuan kontrol diri (Unnever, Cullen dan Agnew, 2006), dan karakter positif (Rakhmawati, 2015). Baumrind (Santrock, 2012) yang menyatakan bahwa Pengasuhan anak yang di lakukan orangtua berdampak pada perilaku anak. Hoghughi dan Long (2004) mendefinisikan pengasuhan anak sebagai serangkaian aktivitas yang bertujuan memastikan anak mampu bertahan hidup dan mengalami proses perkembangan dengan baik. Lebih lanjut Hoghughi dan Long (2004) menyebutkan bahwa pengasuhan anak tidak menekankan pada siapa (pelaku) pengasuhan anak, tetapi menekankan pada aktivitas perkembangan dan pendidikan yang didapat anak.

Hasil penelitian oleh Yayasan Kita \& Buah Hati pada tujuh ribu responden di beberapa kota besar di Indonesia yang telah memiliki anak di berbagai rentang usia, didapatkan sebuah kesimpulan bahwa sebagian besar orangtua tidak pernah merumuskan apa tujuan pengasuhan anak anak-anak mereka (Rasa, 2012). Hal ini juga didukung oleh penelitian Sumargi, Sofronoff dan Morawska (2015) menunjukan bahwa masih banyak orang tua di Indonesia yang melakukan pengasuhan anak yang kurang efektif pada saat menghadapi perilaku anak, dan memiliki pengetahuan terkait pengasuhan anak atau parenting tetapi disisi lain orangtua memiliki minat untuk mengikuti program parenting.

Hal ini juga ditambah dengan tingginya pernikahan dini di Indonesia membuat banyak orangtua yang memiliki anak di usia muda belum siap secara mental memiliki anak yang bisa mengakibatkan pada pola pengasuhan anak yang kurang tepat. Pernikahan muda (early marriage) adalah pernikahan yang dilakukan pasangan muda di bawah 19 tahun (WHO, 2006). Batasan ini sejalan dengan rekomendasi The Elimination of All Forms of Discrimination Against Women (CEDAW) yang menyatakan usia 18 tahun seharusnya menjadi usia minimum untuk menikah baik laki-laki maupun perempuan. Di Indonesia idelanya seseorang harus berusia minimal 21 tahun untuk dapat melangsungkan pernikahan. Hal ini diatur dalam UU Pernikahan Tahun 1974 Pasal 6 ayat 2 .

Menurut BKKBN di Indonesia prevalensi pernikahan dini telah mengalami penurunan lebih dari dua kali lipat dalam tiga dekade terakhir, namun masih termasuk yang tertinggi di kawasan Asia Timur dan Pasifik. Data yang dilansir melalui HarianJogja (2017) sepanjang tahun 2016 di Yogyakarta kasus penikahan dini 
terbanyak ada di Kabupaten Gunungkidul sebesar 11,29\%, diikuti Kota Yogyakarta 7,79\%, Bantul 7,30\%, Kulonprogo 7,28\%, dan Sleman 5,07\%. Menurut Dr Umi Listyaningsih, M.Si., peneliti dari Pusat Studi Kependudukan dan Kebijakan (PSKK) Universitas Gadjah Mada, tingginya angka perniakan dini di Yogyakarta tidak melulu karena kasus kehamilan di luar nikah tetapi memang keinginan remaja di wilayah ini untuk menikah muda. Namun di sisi lain, kesadaran remaja terhadap family planning (perencanaan keluarga) di Yogyakarta masih tergolong rendah (Detiknews, 2016). Mereka cenderung enggan membicarakan berapa jumlah anak yang direncanakan, pemakaian alat kontrasepsi, atau tentang pemberian ASI.

Pasangan yang memutuskan berumah tangga memiliki tugas membangun hubungan pernikahan positif. Salah satu kontributor kepuasan pernikahan ialah kesepakatan mengenai peraturan peran mereka (Brooks, 2011). Pada pasangan berusia muda atau mereka yang baru saja memasuki pernikahan, kesepakatan pada hal-hal ini cenderung diabaikan karena umumnya mereka lebih fokus membangun stabilitas ekonomi dan penyesuaian diri pada tugas-tugas baru. Hal ini sesuai dengan pernyataan Maccoby dan Mcloby (2008) bahwa faktor lain yang mempengaruhi pola asuh dijelaskan oleh yaitu: kondisi sosial ekonomi, pendidikan, nilai agama, kepribadian, dan jumlah kepemilikan anak.

Hal ini terjadi karena pada masyarakat kita, keputusan menikah muda lebih banyak disebabkan oleh faktor-faktor eksternal, antara lain alasan ekonomi, rendahnya tingkat pendidikan, dorongan orangtua, ekspose media massa, faktor adat (Purnawati, 2015), dan pengaruh peergroup (Murcahyo, 2010) Minimnya faktor internal seperti pengetahuan, nilai-nilai pribadi, dan kepribadian menyebabkan pasangan muda kesulitan menetapkan tujuan rumah tangga, termasuk pola pengasuhan anak kepada anak.

Berkaitan dengan hal tersebut perlu adanya upaya membangun pengasuhan anak yang tepat dari orang tua sejak dini. Usia kanak-kanak adalah masa emas atau waktu yang tepat karena anak mempunyai potensi yang sangat besar untuk mengoptimalkan segala aspek perkembangannya seperi aspek moral, sosial, emosi, kognitif, dll sehingga akan membentuk pribadi yang berkualitas baik jika mendapatkan pengasuhan anak yang tepat (Hurlock, 2008), tetapi pengasuhan anak yang tepat tidak mudah untuk dilakukan, masih banyak orangtua yang melakukan pengasuhan anak yang tidak sesuai dan merugikan anak dalam hal psikis maupun fisik.

Berdasarkan hal tersebut menunjukkan pentingnya perencanaan pengasuhan. Pentingnya perencanaan pengasuhan telah mendorong disusunnya berbagai program pemberdayaan berbasis keluarga di seluruh dunia. Healthy Families Massachusetts (HFM) (Jacobs dkk, 2016) adalah program home-visit yang dilakukan di Massachusetts, salah satu negara bagian Amerika Serikat, memiliki tujuan membantu orangtua muda di bidang pengasuhan, perkembangan anak, pendidikan, perencanaan keluarga, kesehatan ibu selama kehamilan, dan kesejahteraan keluarga. HFM adalah program yang menyediakan bantuan 
kunjungan rumah, termasuk didalamnya membantu pasangan muda merancang tujuan rumah tangga, menyediakan kurikulum berbasis aktivitas, family support, screening rutin bagi perkembangan anak, serta berafiliasi dengan penyedia layanan medis dan bantuan lain yang diperlukan. Hasilnya, program HFM memiliki pengaruh positif pada permasalahan stres orangtua, penggunaan kondom, kekerasan rumah tangga, dan problem putus sekolah.

Program lain yang juga dikembangkan pemerintah adalah Parenting Plan, sebuah kurikulum yang disusun untuk membantu pasangan yang bercerai agar anak-anak mereka tetap mendapat hak-haknya dan mendapat prioritas penyelesaian(https://www.cafcass.gov.uk/g rownups/parentingplan.aspx,diakses22/01/2 017, 19.32 WIB). Parenting Plan membantu orangtua merumuskan berbagai isu seputar pengasuhan yang harus disepakati bersama dan akan dijalankan pasca perceraian. Disusunnya program ini berangkat dari data meningkatnya jumlah perceraian di United Kingdom yang akhirnya memicu sejumlah permasalahan seputar pengasuhan dan pendidikan anak.

Program berbasis keluarga yang diujicobakan di Indonesia adalah Triple P (Positive Parenting Program). Program ini menunjukkan hasil adanya penurunan pada problem perilaku anak, praktik pengasuhan yang keliru, stress orangtua, dan peningkatan kepercayaan diri orangtua (Sumargi, Sofronoff, dan Morawska, 2015). Hal ini menunnjukkan bahwa program pengasuhan anak bagi orangtua perlu dilakukan agar orangtua dapat melakukan pengasuhan secara baik dan benar yang nanti akan berpengaruh pada perilaku anak.

Berbagai program pengasuhan berbasis keluarga tersebut menunjukkan pentingnya peran orangtua pada perkembangan dan perilaku anggota keluarga tersebut. Belsky (1984) melalui Model Proses menjelaskan faktor-faktor yang mempengaruhi perilaku pengasuhan orangtua yaitu: kepribadian, kondisi yang memberikan dukungan atau stress dari lingkungan, karakteristik anak, jaringan sosial, serta hubungan pernikahan Ayah dan Ibu. Model ini dikembangkan berdasarkan pemikiran Bronfenbrenner (1977) tentang suatu perspektif mengenai metodologi dalam mempelajari perkembangan kepribadian yang mempertimbangkan aspek-aspek di luar individu, yaitu dari sisi lingkungan dimana individu tersebut berada.

Penelitian ini selanjutnya akan didasarkan pada Model Proses oleh Belsky (1984) tersebut namun dilakukan dalam bentuk potongan model, dalam artian hanya fokus pada beberapa hubungan saja. Pembatasan kajian dalam penelitian ini yaitu pada: dukungan/stress dari lingkungan, jaringan sosial, dan hubungan pernikahan. Pembatasan ini dilakukan karena orientasi penyusunan kurikulum pengasuhan ada pada penguatan peran orangtua. Selanjutnya ketiga hal tersebut akan dikembangkan menjadi profil kebutuhan pasangan muda dalam pengasuhan yang dapat dirumuskan sebagai berikut: 


\begin{tabular}{|c|c|c|}
\hline $\begin{array}{l}\text { Dukungan/stre } \\
\text { ss lingkungan }\end{array}$ & $\begin{array}{c}\text { Jaringan } \\
\text { sosial }\end{array}$ & $\begin{array}{l}\text { Hubungan } \\
\text { pernikahan }\end{array}$ \\
\hline $\begin{array}{l}\text { - Jenis stressor } \\
\text { - Sumberdaya } \\
\text { eksternal }\end{array}$ & $\begin{array}{l}\text { - Nuclear } \\
\text { family } \\
\text { - Extended } \\
\text { family }\end{array}$ & $\begin{array}{l}\text { - Tujuan } \\
\text { pengasuhan } \\
\text {-Bentuk } \\
\text { pengasuhan } \\
\text {-Dimensi } \\
\text { pengasuhan }\end{array}$ \\
\hline
\end{tabular}

Gambar 1. Kerangka penelitian

Dinamika dalam keluarga selalu melibatkan proses penyesuaian akibat adanya perubahan. Carter \& McGoldrick (Goldenberg \& Goldenberg, 1985) menyebut faktor stresor yang dialami keluarga sebagai sumber perubahan. Dua jenis stresor adalah stresor vertikal dan stresor horizontal. Stresor vertikal berupa tekanan-tekanan dari sistem yang lebih besar seperti kondisi ekonomi Negara, prasangka dan sikap sosial, ideologi.

Stresor horizontal berupa transisi tahap perkembangan keluarga dari sisi internal dan krisis dari sisi eksternal seperti bencana, perang, kematian, sakit yang kronis. Perubahan-perubahan semacam ini akan mengguncang keseimbangan dalam keluarga karena keluarga akan berusaha mengatasi masalah yang dihadapi agar kemudian keseimbangan dapat dikembalikan. Apabila keluarga dapat mengatasi masalah dengan baik maka akan terjadi suatu penyesuaian, sementara jika keluarga tidak mampu menyelesaikan masalahnya, yang terjadi adalah krisis yang berkepanjangan.

Sumberdaya eksternal merupakan bentuk dukungan yang diterima keluarga dari lingkungannya. Menurut Sarafino (dalam Taylor, 2006) dukungan dapat berbentuk emosional, penghargaan, informasi, dan instrumental. Persepsi terhadap ketersediaan dukungan sosial memberikan banyak keuntungan. Orangtua dengan dukungan sosial tinggi memiliki tingkat stres yang rendah dan mampu mengatasi kondisi sulit dalam pengasuhan dengan lebih baik.

Sistem keluarga baik nuclear family maupun extended family juga memberikan pengaruh signifikan pada pengasuhan. Andayani (2000) menemukan bahwa ketika relasi dalam keluarga inti banyak dipengaruhi oleh keluarga besar, pengasuhan yang dilakukan orangtua menjadi tidak jelas. Aspek yang teramati terutama muncul pada masalah aturan keluarga yang inkonsisten karena adanya perbedaan ide antara ayah-ibu dan orangtua mereka. Karakteristik masyarakat Indonesia didominasi hubungan yang erat pada extended family. Hal ini menunjukkan perlunya dilakukan pemetaan pengaruh keluarga besar pada pasangan muda.

Pengasuhan juga dilandasi oleh hubungan pernikahan antar suami dan istri. Miller, Cowan, Cowan, Hetherington, dan Clingempeel (1993) dalam penelitiannya menemukan bahwa penyesuaian diri dan penyesuaian pernikahan pasangan orangtua mempengaruhi kualitas cara pengasuhan mereka. Pada subjek ibu ketika hubungan suami-isteri diwarnai afek positif yang rendah, cara pengasuhannya menjadi kurang hangat. Sementara pada subjek ayah ketika hubungan antara suami isteri kurang bagus dan diwarnai dengan banyak konflik perilakunya pada pengasuhan anak menjadi berkurang dari sisi kendali. Penelitian oleh Miller, dkk ini menunjukkan perlunya kesiapan pasangan menikah untuk menjadi orangtua. Kesiapan ini seringkali sulit dilakukan pada orangtua yang kurang memiliki kematangan emosi 
dan kedewasaan berpikir. Di Indonesia idealnya seseorang harus berusia minimal 21 tahun untuk dapat melangsungkan pernikahan. Hal ini diatur dalam UU Pernikahan Tahun 1974 Pasal 6 ayat 2.

Pada praktiknya, mereka yang secara legal telah memasuki usia ideal penikahan ternyata kurang memiliki rencana jangka panjang dalam mengelola rumah tangga, termasuk bagaimana mempersiapkan diri sebagai orangtua. Penelitian oleh Sumargi, Sofronoff dan Morawska (2015) menunjukan masih banyak orang tua di Indonesia yang melakukan pengasuhan kurang efektif pada saat menghadapi perilaku anak. Hal ini terjadi karena transisi menuju kehidupan sebagai orangtua adalah masa yang membutuhkan banyak penyesuaian psikologis. Orangtua muda juga diasosiasikan memiliki kerentanan tinggi pada masalah perceraian, kekerasan dan penelataran anak, depresi, dan perilaku beresiko lainnya (dalam Jacobs dkk, 2016). Hasil studi tersebut memberikan gambaran bahwa meskipun pada usia dewasa awal seseorang telah dinyatakan siap membangun keluarga, namun berbagai tantangan menjadi orangtua muda harus tetap mendapat perhatian serius.

Penelitian ini didesain berlangsung multiyears, dengan capaian yang berjenjang di tiap tahunnya. Fokus penelitian ini untuk mengetahui apa yang sebenarnya dibutuhkan oleh orangtua terkait pengasuhan anak, sehingga penelitian adalah melakukan assessment atau pengumpulan data terkait permasalahan orangtua sehingga tersusun profil need assessment yang bisa menjadi dasar program kurikulum pengasuhan anak orang tua pada penelitian selanjutnya

\section{Metode}

\section{Rancangan Penelitian}

Penelitian ini bersifat penelitian pengembangan, yaitu penelitian secara sistematik menggunakan teori yang telah ada, dengan tujuan untuk menghasilkan model/modul baru. Penelitian bersifat multiyears selama tiga tahun. Adapun model penelitian yang digunakan adalah kombinasi antara penelitian lapangan dan penelitian eksperimen. Penelitian tahun pertama dan kedua merupakan penelitian lapangan, sedangkan penelitian tahun ketiga merupakan penelitian eksperimen. Pendekatan yang dilakukan menggunakan gabungan antara pendekatan kuantitatif dan kualitatif (mix method).

\section{Lokasi dan Subjek Penelitian}

Propinsi DIY terdiri dari empat kabupaten (Gunungkidul, Bantul, Kulonprogo dan Sleman) dan satu kota (Yogyakarta). Masing-masing kabupaten tersebut diambil satu Taman Kanak-Kanak sebagai tempat pengambilan sampel. Karakterikstik orangtua yang masih tergolong pasangan muda umumnya akan ditemui di tingkat TK. Teknik sampling yang digunakan adalah random sampling. Sekolah yang digunakan sebagai tempat pengambilan sample adalah TK Al Muhajirin (Sleman), TK ABA Notoyudan (kota Yogyakarta), TK Khalifah Kids (Gunungkidul), TK ABA Krapyak (Bantul), dan TK PGRI Nanggulan (Kulonprogo).

Kriteria subyek penelitian adalah pasangan suami isteri yang dikategorikan sebagai pasangan muda (berusia maksimal 
30 tahun dan atau usia pernikahan maksimal 5 tahun), mampu berkomunikasi dengan lancar baik secara lisan maupun tulis, serta bersedia menjadi subjek penelitian. Dari masing-masing kabupaten diambil 25-30 subjek untuk mengikuti FGD. Total subjek dalam penelitian ini adalah 132 orang, terdiri dari 16 laki-laki dan 116 perempuan.

\section{Pengumpulan dan Analisis Data}

Pengumpulan data yang digunakan dalam penelitian ini terbagi menjadi dua, pengumpulan data pada tahap need assesment dan tahap intervensi. Pada tahap need assesment, pengumpulan data menggunakan metode diskusi kelompok terarah atau focus group discussion (FGD) sebagai instrumen utama, dilengkapi dengan metode observasi dan studi dokumentasi pendukung. FGD adalah teknik pengumpulan data yang umumnya dilakukan pada penelitian kualitatif dengan tujuan menemukan makna sebuah tema menurut pemahaman suatu kelompok.

Panduan FGD pada penelitian ini disusun berdasarkan 6 aspek yaitu: 1) informasi pengasuhan anak, untuk mengetahui sejauh mana subjek memahami tentang pengasuhan anak dan dari mana sumber informasi yang dipercaya, 2) tujuan pengasuhan anak, untuk mengetahui apa saja tujuan subjek dalam mengasuh putra putrinya, bagaimana tujuan tersebut disusun dan dievaluasi, 3) bentuk pengasuhan anak, untuk mengetahui apa model pengasuhan anak yang dilaksanakan Ayah dan Ibu dan apakah ada keselarasan di antaranya, 4) persepsi diri, untuk mengetahui bagaimana orangtua melihat dirinya dalam proses pengasuhan anak, 5) pengaruh lingkungan, untuk melihat sejauh mana lingkungan sosial mempengaruhi pengasuhan anak, dan 6) hambatan pengasuhan anak, untuk mengetahui apa saja hambatan yang dirasakan orangtua baik secara eksternal maupun internal.

Pengumpulan data berupa Focus Group Discussion (FGD) dilaksanakan bertahap pada 29 Juli di Sleman, 21 Agustus di Kota Yogyakarta, 25 Agustus di Bantul, 25 September di Gunung Kidul, dan 28 Oktober di Kulon Progo. Sejumlah orangtua murid mendapat pemberitahuan mengenai agenda ini lalu bagi yang bersedia berpartisipasi dapat hadir secara sukarela di sekolah masing-masing. Setiap pelaksanaan FGD team peneliti dibantu oleh fasilitator, observer, dan bagian perlengkapan. Anggota team lapangan ini berasal dari Prodi Psikologi dan Prodi Pendidikan Anak Pendidikan Anak Usia Dini (PGPAUD).

Pada masing-masing tempat dibagi menjadi empat kelompok FGD dengan jumlah partisipan antara 5-7 orang. Pembagian kelompok dilakukan secara acak di awal acara, namun tetap memastikan apabila ada pasangan suami istri yang ikut, maka dipisah ke dalam kelompok berbeda. Durasi pelaksanaan FGD berkisar antara 1,5 - 2 jam. Analisis data penelitian ini menggunakan thematic analysis.

\section{Hasil}

Tujuan penelitian ini adalah menyusun profil kebutuhan pasangan muda dalam pengasuhan anak. Untuk mencapai tujuan tersebut, FGD disusun ke dalam tiga aspek utama: dukungan dan stress dari lingkungan, jaringan sosial, dan hubungan dalam pernikahan. Ketiga aspek 
tersebut diturunkan lagi ke dalam tujuh sub-aspek: jenis stressor, sumberdaya eksternal, nuclear family, extended family, tujuan pengasuhan, bentuk pengasuhan, dan dimensi pengasuhan.

\subsection{Jenis stressor}

Stressor orangtua dalam pengasuhan anak ada dua jenis yaitu stressor dari dalam diri (internal) dan stressor dari luar (eksternal). Hambatan dari dalam diri seperti kurangnya pengetahuan terkait pengasuhan anak sehingga terkadang bingung menghadapi perilaku-perilaku anak yang tidak sesuai harapan orangtua. Selain itu orangtua merasa sangat kesulitan untuk mengendalikan emosi dan bersikap sabar terhadap perilaku anak sehingga terkadang muncul perilaku yang tidak sesuai kepada anak seperti berkata kasar, marah-marah, memberi label negative pada anak seperti "nakal", "bandel", bahkan ada yang sampai pada hukuman fisik, walaupun pada akhirnya orangtua menyesal sendiri atas perlakuan yang telah orangtua berikan kepada anak. Selain itu keterbatasan waktu dan tenaga orangtua untuk memperhatikan anak, karena orangtua seharian sudah sibuk bekerja.

"Kadang ga mau marah tapi kadang kalo ngeselin banget, kakak ngeselin banget sih, nakal banget dah pasti keluar itu.."

Kalau saya lebih kalo misalnya saya lagi ada kerjaan... saya kan kerja di kantor advokat yah... kalo ada deadline yag harus diajukan ke persidangan apaaaa..gitu...kadang misalkan anak minta ditemenin atau apa gitu... kagol... kadang jeleknya itu..."

Hambatan dari luar (eksternal) yang dapat mempengaruhi pengasuhan anak adalah adanya pengaruh lingkungan seperti pengaruh TV dan Gagdet, tidak adanya pemahaman yang sama antara orangtua dengan anggota keluarga lain dalam pengasuhan anak anak, sikap kritis dari anak-anak sehingga cenderung susah untuk diatur atau dikendalikan.

"Kalo saya dari tv, soalnya sekarang kan banyak sinetron kayak jodoh ee kayak di antv itu, itu kan member dampak yang ga bagus.."

"Kalo saya terus terang... kalo tinggalnya itu bukan dengan bapak/ibu nya artinya dari eee ada orang lain ee bukan orang lain yah... saudara misalnya pak de nya itu ada disitu eee cara berpikir... eee komitmen kan suami dan istri kan udah komitmen ini, tapi kalo sama pakdenya itu kan beda pendapat jadi anaknya bingung. Ini yang mau dituruti itu siapa. Jadi bingung. Kalo saya itu..."

1.2. Sumberdaya eksternal

Lingkungan memberi dampak positif maupun negative dalam pengasuhan anak. Dampak positif yang didapat dari lingkungan seperti mengikuti perilaku positif temannya (sholat dan mengaji di masjid), perkembangan bahasa berkembang maksimal, lebih berani, lebih kreatif dan dapat bersosialisasi dengan baik. Dampak negative yang didapat dari lingkungan seperti adanya perilaku negative seperti suka memukul, lupa waktu pada saat bermain, prestasi akademik menurun, berkata kasar dan kurang sopan.

"Kalo kebanyakan tetangga saya itu, ga pernah ada yang... nganu itu loh belajar itu loh... jadi semua main... jadinya kan sukar kan mau diajar kan, yg lainnya ga belajar..."

"Positifnya kan bisa sehat, ngasah syaraf motoriknya juga. Lalu bisa bersosialisasi. Negatifnya ya itu kecapean."

"Pengaruhnya ya TPAnya itu karena dekat masjid kalo temen-temennya banyak yang berangkat disuruh berangkat langsung berangkat." 
Beberapa orangtua dalam pengasuhan anak orangtua dibantu atau didominasi oleh nenek atau keluarga besarnya. Hal ini secara langsung dan tidak langsung membawa pengaruh terhadap pola pengasuhan anak yang sudah ditetapkan oleh orangtua. Beberapa efek yang diterima jika pengasuhan anakn didominasi oleh nenek atau keluarga besar yaitu anak menjadi manja, ngeyel, komsumtif, anak lebih dekat dengan orang lain dari pada orangtuanya, aturan yang sudah ditetapkan orangtua tidak bisa berjalan dengan baik karena ada campurtangan orang lain/ketidak sepahaman cara mengasuh.

"ada tapi beda rumah tapi cuma kadangkadang. Kalau anak saya yang pertama itu kalau pas ditinggal ibunya sama bulek saya, jadi cuma depan rumah. Nah itu beda sekali sama adekadeknya, dia ada apa-apa mesti larinya ke sana. Misalnya bapak ibunya ga boleh minta uang misalnya "mau jajan ini" "ga boleh" dia lari ke tempat sana."

"Ya pengaruhnya jadi ngeyel..."

"Saya kadang sama mbah putri, mbah kakungnya... kalo ini ya cuma. Kadang kalo pas saya lagi marah, pas saya agak marah atau apa... "aku ndak diseneni ibu e mbah" terus nanti si mbahnya suka nganu... "sama anake ojo kasar... sesok koe tua ne dadi mbah"

"Sama simbahnya yang penting meneng ngoten to, biar ga nakal atau apa kalau minta apa ya diturutin, jadi kan lebih manja..."

1.3. Nuclear family dan Extended Family

Peran pengasuhan anak banyak didominasi oleh ibu dari pada ayah. Hal ini dikarenakan oleh beberapa faktor seperti Ayah bekerja di luar kota, ayah sibuk bekerja sehingga kadang pulang malam hari. Sebagian besar peran ayah dalam pengasuhan anak adalah sebagai penasehat bagi anak-anaknya, pengingat bagi pasangannya dan pendukung pengasuhan anak. Dalam beberapa keluarga ayah dan ibu memiliki peran yang sama tetapi ada juga peran pengasuhan anak lebih banyak di pegang oleh nenek karena kedua orangtua sibuk bekerja.

"Yang berperan... mungkin ada pas budenya datang. Keluarga besarnya itu... juga suka berikan masukan-masukan..positif.

"Yang berperan mbah kakung, mertua..."

"Kalo saya... anak saya sama suami saya itu lebih condong lebih... anak saya lebih sukanya baca cerita, jadi kalo suami saya cerita itu lebih suka berimajinasi jadi anak saya itu paham. Terus hobbynya juga suami saya suka olahraga, anak saya juga suka olahraga anak saya juga... kalo ke saya itu kadangan lebih cendrung kayak mengerjakan sesuatu kayak menggambar atau belajar atau apa gitu ke saya, tapi kalo menceritakan suatu buku cerita atau televise ceritanya seperti apa lebih ke suami saya.."

"Apalagi udah capek banyak kerjaan wes rasaneee. Kadang enggak bisa berpikir panjang gitu lho, ini nanti anak harus tidur, habis ini ibunya mau gini harus ini, kemrungsung sek. Anaknya malah enggak tidur-tidur, masuk kamar jam 2 tidurnya malah jam 4, waduuuuh itu ibunya dulu yang tidur. Ibu e turu anake dolan hahaha"

\subsection{Tujuan pengasuhan anak}

Sebagian besar orangtua menyusun tujuan pengasuhan anak orangtua setelah orangtua memiliki anak, bahkan beberapa orangtua dalam mengasuh anak mengalir begitu saja, tanpa perencanaan dan tidak ada evaluasi terkait tujuan pengasuhan anak. Orangtua ada yang merencanakan pengasuhan anak anak terutama terkait cara memperlakukan anak dengan baik dan rencana terkait pendidikan. Beberapa Orangtua juga melakukan evaluasi terkait tujuan pengasuhan anakn mereka. Hal ini 
sesuai dengan pernyataan beberapa subjek dibawah ini:

"mengalir aja"

"selama ini sudah seperti itu yah... tentang sekolahnya, kuliah..."

"Kalo anak pertama mungkin karena anak pertama yah... jadi kesenenngannya di cublek, dijiwit kok anaknya santai aja... lah bocah $e$ loro. Kok ra eneng perubahan, yaudah yang adek-adeknya gag a ga sama sekali saya cubit, saya cublek... hahaha santai aja gitu. Yang penting dia tau tanggung jawab dia kalo dia begini itu resikonya begini..."

Beberapa orangtua membuat tujuan pengasuhan anak dibuat bersama-sama dengan pasangan dengan dikomuikasikan terlebih dahulu dan saling mengingatkan jika tidak sesuai tetapi tidak depan anak langsung. Disisi lain beberapa orangtua lebih memasrahkan pengasuhan anak pada ibu dan jarang ada komunikasi dengan pasangan karena beberapa factor seperti suami yang cenderung pendiam, suami yang memandang istrinya lebih bisa mengasuh dan suami yang cenderung sibuk. Hal ini sesuai dengan pernyataan beberapa subjek dibawah ini:

"Jarang, wong orangnya pendiem"

"Inggih to..hawong nyambut gawe wae dadi nek ming kober tok"

"Itu orang tua harus ada komunikasi, komunikasi kan penting, makanya kita harus sebelum menghadap anak ada kesalahan atau enggak, kita orang tua harus diskusi dulu sebelumnya, gimaana kalau anak kita melakukan ini. apakah orang tua harus ada pembelaan atau enggak. Iya, soalnya nanti kan kalau anak ga digituin sampai dewasa cari pembelaan. Kalau dia merasa salah, oh aku ada yang bela kok, gitu."

Harapan orangtua terhadap anak adalah lebih pada sikap dan perilaku anak yang sesuai dengan nilai-nilai agama (sholeh/sholehah), mandiri, disiplin dan tanggung jawab, anak bisa lebih sukses dari pada orangtuanya dan harapan secara akademis.

"Semoga anaknya jadi anak pinter, anak soleh, patuh sama orang tua, Negara, yaa pokoknya jadi anak disiplin ya, bangun yang pagi ya.."

"kalau saya mbak, yang penting anaknya tu bisa kayak temen e waktunya solat ya solat waktunya belajar ya belajar, main tu ga perlu dari pulang sekolah sampai maghrib itu ga perlu, saya pinginnya anak saya kayak gitu, solat jangan dilupakan"

1.5. Bentuk pengasuhan anak

Bentuk pengasuhan anak yang diterapkan orangtua berbagai macam, ada orangtua yang membebaskan anaknya (permisif) sehingga tidak menetapkan target kepada anaknya, dan ada orangtua yang tetap memberikan kebebasan anak tetapi dengan tetap memberikan pengawasan dan control terhadap perilaku anak (bentuk otoritatif). Sikap otoriter juga digunakan beberapa orangtua. Orangtua dalam mengontrol perilaku anak dengan cara diingatkan, diawasi, berkoordinasi dan bekerjasam dengan sekolah, berkomunikasi dengan anak atau teman-temannya dan menggunakan system reward dan punishment. Beberapa teknik yang digunakan orangtua untuk mengontrol perilaku anak kadang berhasil kadang juga tidak. Jika gagal dengan teknik yang sudah digunakan orangtua akan berusaha mencari cara lain seperti memarahi, mengancam pergi, tetapi ada yang kemudian menyerah. Hal ini sesuai dengan pernyataan subjek dibawah ini:

"Gak pernah ngasih target? Targetnya yang ringan-ringan sesuai dengan umur 
anaknya? Ga pernah, kalo ditekan-tekan terus malah stres anaknya."

"Ya harus dikontrol mainnya sama siapa? Gak boleh jauh-jauh."

"Kalo anak saya misalnya anak saya dia saya suruh bobok misalnya kalo dikasiha yakul itu kan susah mbak. Ya kalo bilang ayo tidur nanti bangun tidur kasih yakul."

"Biasanya keras..ngobrol sama ayahnya gini-gini...gini yo sebisa mungkin tak tahan gitu loh coba diginiin anaknya bisa nurut apa gak. Kalau caranya mendidik kayak gini dia gak mau gimana caranya kalo dengan pelan..pelan..pelan ndak bisa ya gimana lagi."

"Iya mendidik kan saklek gitu tho hehehe ya kadang-kadang kan kasihan tapi kita kan harus ya piye gitu ya tegas"

Beberapa target orangtua untuk anaknya seperti perilaku yang baik (mandiri, disiplin, dapat bersosialisasi dengan baik, melaksanakan sholat) dan prestasi akademik yang bagus. Usaha yang dilakukan orangtua untuk membantu anaknya dalam mencapai target adalah membimbing, mengingatkan, memberi sugesti positif bagi anaknya dan menjadi contoh bagi anaknya, mengkomunikasikan keinginan orangtua dan disekolahkan (memberi pedidikan dan ilmu pengetahuan).

"Ya jadi anak yang soleh anak baik ee tau agama memperdalam bisa menghayati nanti besarnya..."

"Kalau saya, harapan setiap orang tua kan mesti pingin yang terbaik istilahnya berguna bagi nusa, bangsa, negara, dan agama sama orang tua baik dari sisi agama, dari sisi pendidikan, sekolah, atau edukasi tentang istilahnya ilmu-ilmu lah"

"Kalau aku nyontohin kita sendiri."

"Sugestinya kan dikuping dibisikin misal jadi anak yang baik, anak yang pinter tapi tau enggak tau ya mbak dia sambil tidur itu jawab "iya, iya".
Beberapa yang menjadi topik komunikasi orangtua dan anak adalah lebih pada kesenangan/minat anak dengan alasan supaya terjalin komunikasi yang erat dengan orangtua. Topik komunikasi lainnya adalah terkait teman, sekolah dan pelajaran.

"Ya hampir sama, ya dari kesenengan anak itu apa ambilnya dari situ aja. Lama-lama kan dia jadi cerita sendiri dengan tidak sadar kan jadi tau. Kadnag kita kan kalo disekolah ya ngapain... kak tadi disekolah ngapain? Dia gamau cerita. Tapi kalo kita pancing kesenengannya apa... lama-lama secara ga sadar maalah cerita sendiri. kita taunya dari situ."

"Tanya tadi gimana cerita temennya ngapain, gurunya gimana, kok ini enggak bisa kenapa "Ini susah ma, tadi udah nanya tapi masih bingung" ya gitu aja kalo malem ngobrol ya saya ya bapaknya kadang adeknya juga ikut dengerin".

1.6. Dimensi Pengasuhan

Orangtua memahami pengasuhan anak sebagai proses yang lebih sempit dibanding mendidik. Pengasuhan anak berfokus pada pemenuhan fisik anak seperti memberi makan, menjaga kesehatan, melindungi dari penyakit, dan membesarkan anak. Sementara itu mendidik diartikan sebagai penanaman budi pekerti, karakter, dan proses menyekolahkan anak. Hal ini sesuai dengan pernyataan peserta dibawah ini.

"mengasuh itu mengarahkan dia kearah yang lebih positif, kalo mendidik itu membesarkan dia harus mendapatkan asupan gizi makanan yang teratur dan mendidik itu dengan apa yaah... menyekolahkan dia, ,"

"Kalau mendidik itu ya menjadikan anak itu bagaimana mengerti paling enggak ketika peraturan yang kita terapkan harus di ini terus kedisiplinan. Kalau membesarkan ya kita kasih makan, merawat, memandikan, kasih sayang" 
Informasi mengenai pengasuhan anak didapatkan orangtua melalui berbagai sumber seperti dari pengalaman orangtua, tetangga, membaca buku parenting, internet, maupun acara parenting yang diadakan sekolah dan dapat disimak melalui media televisi. Orangtua merasa informasi tersebut masih minim sehingga tidak jarang masih menemui kesulitan mengatasi problem pengasuhan anak. Apa yang didapat melalui sumber-sumber tersebut kemudian dimodifikasi sesuai kebutuhan anak dan disesuaikan kemampuan. Hal ini bisa terlihat dari beberapa pernyataan peserta dibawah ini:

"Terus pengalaman liat tetangga, tidak tidak sampe sekolah haha"

"Pengalaman, sedikit banyak dari internet ya"

"Ya dari informasi yang saya dapat, $e$ pertama saya ikut parenting kan sekolah nih yang buat ya saya coba aja apa yang saya terima diterapkan ke anak-anak terus nanti ya saya sesuaikan dengan karakter anak-anak saya, kan tiga anak karakternya beda-beda"

"Anu anak sayakan SD mbak itukan makan nasi gak mau dulu ma masih kecil mau terus sedangkan saya sendiri kalo gak mau saya dia minta apa ya saya kasih. Sampe sekarangkan gak mau, kemarin waktu liburan tak paksa maem nasi to le, rasah dipaksa to bu ngko wis gelem makan nasi sampe panas dia tak periksa udah makane nek tapi dia udah berusaha mandiri, makane nek istirahat saya musti harus anu bar dateng nanya padahal dari sekolah mesti ada makanan nanti setengah sepuluh saya menganter makanan. Saya minta solusinya gimana gitu lo".

\section{Diskusi}

Respon peserta dalam aspek pengetahuan menunjukkan masih rendahnya pemahaman peserta mengenai dimensi pengasuhan anak. Brooks (2011) menyebutkan pengasuhan anak merupakan proses dimana orangtua secara aktif menyediakan lingkungan yang aman dan memelihara bagi anak. Lingkungan yang dimaksud disini meliputi lingkungan fisik, sosial dan psikologis. Pemaknaan peserta bahwa mengasuh hanya fokus pada pemenuhan fisik saja mengindikasikan bagaimana orangtua memposisikan diri sebagai penyedia kebutuhan anak, dan tidak melihat pengasuhan anak sebagai relasi yang mampu membangun satu sama lain.

Pentingnya orangtua memahami arti pengasuhan anak diperkuat oleh sejumlah penelitian yang menyebutkan persepsi orangtua tentang model pengasuhan anak yang mereka lakukan berkorelasi positif dengan keberhasilan akademik (Phillipson dan McFarland, 2016), kesehatan mental dan kepuasan hidup anak (Abubakar dkk, 2014), serta kemampuan anak berfungsi dalam lingkungannya (Alsheikh, Parameswaran, \& Elhoweris, 2010). Berbagai literasi tersebut menunjukkan bagaimana orangtua merepresentasi diri mereka pada akhirnya mempengaruhi pola sikap yang dikembangkan terhadap anak. Orangtua yang melihat pengasuhan anak sebagai hubungan materialistik seperti pemenuhan sandang, pangan, papan, maka evaluasi mereka pada kualitas pengasuhan anak juga akan terbatas pada aspek materialistik.

Hasil ini berkaitan juga dengan temuan bahwa Ibu lebih berperan dalam menetapkan tujuan pengasuhan anak dan melaksanakan nilai-nilai keluarga yang telah disepakati bersama Ayah. Peran 
sentral ibu dalam pengasuhan anak didominasi kepercayaan bahwa tugas utama Ayah ada di ruang publik sebagai pencari nafkah yang harus memenuhi kebutuhan keluarga. Tercapainya tugas ini yang selanjutnya menjadi tolak ukur Ayah melihat perannya dalam pengasuhan anak. Ayah merasa cukup memasrahkan pengasuhan anak pada Ibu selama Ayah mampu memenuhi kebutuhan keluarga, sementara itu pada pertanyaan pendalaman, para Ibu merespon dengan harapan agar Ayah bisa lebih berperan dalam proses tumbuh kembang anak. Ketimpangan peran ini terjadi dalam jangka waktu lama sehingga konsekuensi logis lainnya terjadi ketidakselarasan pola pengasuhan anak antara Ayah dan Ibu.

Perbedaan pola asuh antara Ayah dan Ibu ini oleh Tavvasolie, dkk (2016) disebut sebagai ruang yang harus segera diselesaikan sebab berpotensi memicu konflik internal keluarga. Phillipson \& McFarland (2016) juga mengemukakan perbedaan ini dapat mempengaruhi persepsi anak terhadap orangtua, perkawinan, dam keluarga, akan tetapi, hal ini bukan berarti Ayah dan Ibu harus selalu memiliki kesamaan pola pengasuhan anak. Menurut Horvath, Lee, dan Bax (2015) meskipun Ayah dan Ibu memiliki respon yang berbeda, namun apabila mereka memiliki tujuan yang sama maka pengasuhan anak tetap berjalan efektif, oleh sebab itu meskipun Ayah dan Ibu memiliki memiliki latar belakang yang berbeda, sejak awal perlu dirumuskan bagaimana pola asuh yang akan ditetapkan dan apa tujuan pengasuhan anak yang akan dicapai .

Indikator lain perbedaan pola asuh yang menjadi temuan dalam FGD ini ditunjukkan oleh pernyataan Ibu yang mayoritas menganggap antara dirinya dan suami memiliki kecenderungan gaya otoritatif. Gaya otoritatif ini orangtua menunjukkan dukungan pada perilaku konstruktif anak, mendasari tindakannya pada rasio atau pemikiran, dan memilih pendekatan yang hangat pada anak-anak (Hurlock, 2002). Pernyataan-pernyataan lain diketahui gaya otoritatif ini lebih sering dilaksanakan oleh Ibu, sementara Ayah cenderung bersikap permisif atau otoritarian. Hal ini dapat dilihat pada sikap Ayah yang umumnya kurang hangat, berkomunikasi seperlunya dan sepihak, serta memberikan hukuman yang tidak sesuai dengan kesalahan anak. Temuan ini sejalan dengan data penelitian MagnisSueno (dalam Abubakar dkk, 2014) bahwa meskipun Ayah di Indonesia memegang peranan sebagai "pemimpin", namun Ayah cenderung menjaga jarak dengan anak dan memberikan hukuman jika diperlukan. Di sisi lain, Ibu lebih berperan pada pembentuka kedisiplinan dan pertumbuhan anak. Hasil ini mengindikasikan perbedaan pola asuh tersebut ternyata tidak sepenuhnya disadari oleh orangtua.

Analisis pada aspek tujuan pengasuhan anak, menemukan bahwa peserta pada umumnya menyusun tujuantujuan jangka panjang namun tidak disertai indikator ketercapaian yang achieveable dan bertahap. Orangtua juga tidak memiliki strategi konkrit bagaimana akan mencapainya. Hastings dan Grusec (dalam Horvath, Lee, dan Bax) menyebutkan orangtua harus memiliki tujuan yang memiliki dimensi waktu (jangka pendek dan jangka panjang), serta fokus perhatian 
(diri sendiri, anak, dan hubungan orangtuaanak). Keseimbangan antar dimensi tersebut berkorelasi positif pada perilaku pengasuhan anak (Dix dkk, 2004).

Respon peserta dalam FGD menunjukkan tujuan pengasuhan anak anak yang diinginkan antara lain: berperilaku sesuai nilai keagamaan (jangka panjang-fokus pada orangtua), memiliki kehidupan lebih baik dari orangtua (jangka panjang-fokus pada orangtua), berhasil secara akademik (jangka panjang-fokus pada orangtua), mampu mandiri (jangka panjang-fokus pada anak). Berbagai tujuan itu dilontarkan secara generik tanpa memperhatikan kebutuhan pengasuhan anak itu sendiri. Kesimpulan dari analisis tematik ini menunjukkan perlunya orangtua membuat tujuan pengasuhan anak jangka pendek yang berorientasi pada anak dan pada kualitas hubungan orangtua-anak, seperti "membantu anak menemukan minat yang dapat dikembangkan", "memperbaiki cara berkomunikasi verbal" atau "menjaga kepercayaan yang anak berikan"

Temuan lain dari penelitian ini adalah besarnya pengaruh lingkungan dalam pengasuhan anak. Hal ini tidak lepas dari budaya Indonesia yang menganut sistem extended family dan memiliki nilai-nilai kebersamaan tinggi. Pengalaman orangtua terdahulu merupakan sumber informasi Tabel 1.

Profil Kebutuhan Pengembangan Kurikulum Pengasuhan anak penting dalam membentuk pola asuh, ditambah besarnya peranan kakek-nenek yang juga cukup besar dalam pengasuhan anak. Hal ini rentan memicu konflik manakala perilaku pengasuhan anak dari extended family ternyata berbeda dengan orangtua.

Tucker dan Johnson (dalam Traustadottir dan Sigurjonsdottir, 2008) menyatakan, keluarga besar dapat berfungsi sebagai pendorong kompetensi atau justru penghambat kompetensi orangtua. Berfungsi sebagai pendorong apabila keluarga meletakkan kekuatan pengasuhan anak tetap pada orangtua, mendorong dan mengembangkan ketrampilan, meningkatkan harga diri, serta rasa berharga orangtua, sebaliknya, keluarga juga dapat berperan menyebabkan orangtua kehilangan ketrampilan pengasuhan anak, merasa tidak berharga, dan tidak memiliki kemerdekaan. Untuk itu, sebagai orangtua yang cenderung membutuhkan peran extended family sebagai bagian dari pengasuhan anak, orangtua perlu dibekali pengetahuan dan ketrampilan bagaimana memberdayakan keluarga dengan positif.

Berdasarkan keseluruhan analisis tersebut, dapat disimpulkan kebutuhan orangtua dalam pengembangan kurikulum pengasuhan anak adalah sebagai berikut: 


\begin{tabular}{|c|c|c|c|c|}
\hline $\begin{array}{c}\text { Dimensi } \\
\text { Pengasuhan } \\
\text { anak }\end{array}$ & $\begin{array}{c}\text { Tujuan } \\
\text { Pengasuhan } \\
\text { anak }\end{array}$ & $\begin{array}{c}\text { Bentuk } \\
\text { Pengasuhan } \\
\text { anak }\end{array}$ & Framework & $\begin{array}{l}\text { Mengatasi } \\
\text { Hambatan }\end{array}$ \\
\hline $\begin{array}{l}\text { 1. Fisik } \\
\text { 2. Afektif } \\
\text { 3. Kognitif }\end{array}$ & $\begin{array}{l}\text { 1. Fokus pada } \\
\text { diri } \\
\text { 2. Fokus pada } \\
\text { anak } \\
\text { 3. Fokus pada } \\
\text { hubungan } \\
\text { orangtua- } \\
\text { anak }\end{array}$ & $\begin{array}{l}\text { 1. Tuntutan } \\
\text { 2. Kontrol } \\
\text { 3. Respon } \\
\text { 4. Penerimaan }\end{array}$ & $\begin{array}{l}\text { 1. Diri sendiri } \\
\text { 2. Nuclear } \\
\text { family } \\
\text { 3. Extended } \\
\text { family }\end{array}$ & $\begin{array}{l}\text { 1. Internal } \\
\text { 2. Eksternal }\end{array}$ \\
\hline
\end{tabular}

Pada dimensi pengasuhan anak, orangtua perlu memahami bahwa konsep mendidik dan mengasuh merupakan satu kesatuan yang melibatkan aspek fisikpsikomotor, afektif, dan kognitif anak. Untuk mencakup keseluruhan aspek tersebut, orangtua perlu merencanakan tujuan pengasuhan anak yang tidak hanya fokus pada kebutuhan orangtua, tetapi juga kebutuhan anak sebagai individu, dan kebutuhan hubungan orangtua-anak. Tujuan ini perlu disusun dan dievaluasi secara berkala baik dalam jangka panjag maupun pendek, sehingga dapat dilakukan penyesuaian apabila diperlukan. Dalam model pengasuhan anak, orangtua perlu menerapkan bagaimana keseimbangan antara tuntutan, kontrol, respon dan penerimaan. Hal ini penting dilakukan sebab melalui pola asuh inilah tujuan pengasuhan anak yang sebelumnya telah disusun akan dicapai.

Aspek framework merupakan pengembangan dari hasil temuan penelitian ini. Pentingnya orangtua mampu melihat diri secara utuh akan mempengaruhi sikap dan persepsinya pada lingkungan luar, dalam hal ini keluarga inti (nuclear family) dan keluarga besar (extended family). Tidak dapat dipungkiri pada pasangan muda yang memiliki anak usia dini, peran kelurga sangat besar dalam tumbuh kembang anak. Pada aspek ini orangtua perlu berlatih mengevaluasi diri, memiliki kesepahaman dengan pasangan, mengkomunikasikan pikiran dan perasaan, hingga mendorong anggota keluarga lain menciptakan iklim pengasuhan anak yang positif.

Aspek terakhir yaitu mengatasi hambatan dalam pengasuhan anak. Berbagai hambatan ini dibagi menjadi dua yaitu hambatan dari dalam diri sendiri dan dan hambatan dari luar. Bentuk hambatan tersebut antara lain: ketidakmampuan mengontrol emosi, belum mampu menjalankan peran sebagai role model, kurang hangat dalam berkomunikasi, mengatasi pengaruh negatif lingkungan, dan mengatasi stigma.

\section{Kesimpulan}

Berdasarkan hasil analisis dapat disimpulkan bahwa pengembangan kurikulum pengasuhan anak untuk pasangan muda perlu dilakukan. Masih banyak orangtua yang melakukan pengasuhan anak tanpa memiliki panduan dan tujuan yang jelas, sehingga berdampak pada perilaku mereka pada anak. 
Gambaran profil kebutuhan untuk pengembangan kurikulum pengasuhan anak terdiri dari lima aspek yaitu: (1) dimensi pengasuhan anak yang terdiri dari dimensi fisik, kognitif, dan afektif; (2) tujuan pengasuhan anak yang berfokus pada diri sendiri, anak, dan hubungan orangtua-anak; (3) bentuk-bentuk pengasuhan anak berupa tuntutan, kontrol, respon, dan penerimaan; (4) framework yang meliputi nuclear family dan extended family; serta (5) cara mengatasi hambatan pengasuhan anak baik internal maupun eksternal.

Saran

Pada tahap berikutnya yaitu penyusunan model kurikulum pengasuhan anak, diharapkan memperhatikan sasaran pelatihan tidak hanya pada aspek kognitif saja, tetapi juga afektif dan psikomotor. Hal ini penting dilakukan sebab masih banyak orangtua belum memiliki keselarasan antara apa yang mereka pahami dengan apa yang mereka rasakan dan harus mereka lakukan. Sebaiknya kurikulum juga disusun dengan melibatkan kedua orangtua agar timbul kerjasama yang optimal antara Ayah dan Ibu. Bentuk penyajian modul sebaiknya disusun dalam bentuk langkahlangkah praktis sehingga orangtua tidak mengalami kesulitan mengikutinya.

\section{Daftar Pustaka}

Abubakar, A., Van de Vijver, Fons, J, R., Suryani, Angela, O., Handayani, P., Pandia, W, S. (2014). Perception of Parenting Styles And Their Associations With Mental Health and Life Satisfaction Among Urban Indonesian Adolescent. J Child Fam Stud, Vol.24 (2680-2692)
Aisyah, et.al.. (2008). Perkembangan dan Konsep Dasar Pengembangan Anak Usia Dini. Jakarta: Universitas Terbuka.

Alsheikh, N., Parameswaran, G, \& Elhoweris, H. (2010). Parenting Style, Self-Esteem and Student Performance in the United Arab Emirates. Current Issues in Education, 13(1). Retrieved from http://cie.asu.edu

Badan Pusat Statistik. (2010). Profil Kriminalitas Remaja 2010. Jakarta:BPS

Brooks, Jane. (2011). The Process of Parenting. New York:McGraww-Hill Companies

Dix, T., Gershoff, E. T., Meunier, L. N., \& Miller, P. C. (2004). The affective structure of supportive parenting: Depressive symptoms, immediate emotions, and child-oriented motivation. Developmental Psychology, 40, 12121227.

Fadlyana, E. \& Larasaty, S. (2009). Pernikahan Usia Dini dan Permasalahannya. Sari Pediatri, 11(2), 136-140.

https://www.unicef.org/indonesia/id/Lapor an_Perkawinan_Usia_Anak.pdf, diakses pada 22/01/2017 pukul 16.25

https://www.cafcass.gov.uk/grownups/parenting-plan.aspx, diakses 22/01/2017, pukul 19.32

http://www.harianjogja.com/baca/2016/11/0 1/pernikahan-dini-rawan-perceraiandan-bunuh-diri-765203, diakses 06/03/2017, pukul 20.47

http://news.detik.com/berita/3261415/peneli ti-ugm-pernikahan-dini-di-yogya-takselalu-karena-kasus-hamil-duluan, diakses 06/03/2017, pukul 20;57

Hurlock, E. (2002). Psikologi Perkembangan suatu Pendekatan Sepanjang Rentang Kehidupan. Jakarta: Erlangga. 
Hurlock, E. B. (2002). Perkembangan Anak Jilid I. Jakarta: PT.Gelora Aksara Pratama.

Hoghughi, Masud.S., \& Long, Nicholas. (2004). Handbook of Parenting : Theory and Research For Practice. Sage Publications.

Jacobs, F., Easterbrooks, A., Goldberg, J., Mistry, J., Bumgarner, E., Raskin, M., Fosser, N., Fauth, R. (2016). Improving Adolescent Parenting: Results from A Randomized Controlled Trial of A Home Visiting Program for Young Families. American Journal of Public Health, 106(2), 342-349

Maccoby, E.E \& Mcloby. (2008). The Two Sexes: Growing Up a Part, Coming Together. Cambridge: Harvard University Press

Nurani, A.S. (2004). Pengaruh Kualitas Perkawinan, Pengasuhan anak Anak dan Kecerdasan Emosional terhadap Prestasi Belajar Anak. Thesis. Institusi Pertanian Bogor.

Purnawati, Laily. (2015). Dampak Perkawinan Usia Muda Terhadap Pola Asuh Keluarga (Studi di Desa Talang Kecamatan Sendang Kabupaten Tulungagung). Jurnal Publiciana, 8(1), hal 53-70

Phillipson, S.,\& McFarland, L. (2016). Australian Parenting and Adolescent Boys' and Girls' Academic Performance and Mastery: The Mediating Effect of Perceptions of Parenting and Sense of School Membership. J Child Fam Stud, 25, 2021-2033

Rakhmawati, Istina. (2015). Peran Keluarga dalam Pengasuhan anak Anak. Jurnal Bimbingan Konseling Islam. 6(1), h.1-18

Rasa, A.A. (2012). Tujuan Pengasuhan anak Anak oleh Bunda Elly Risman. http://deenscreens.tumblr.com/post/33 069582896/tujuan-pengasuhan anakanak-oleh-bunda-elly-risman

Sanders, M., (2012). Development, Evaluation, and Multinational Dissemination Of a Triple P-Positive Parenting Program. Annual Rev Clinical Psychology, 8:435-379

Santrock, J. W. (2012) Life span development. Alih bahasa: B. Widyasinta \& N. I. Sallama. Jakarta: Penerbit Erlangga.

Siswanto, E., (2014). Pengasuhan anak Orang Tua Dalam Pembelajaran Nilai Moral Pada Anak Usia Dini Keluarga TKW Dalam Peer Group Bermain Di Dusun Ngepeh, Desa Sukorejo, Kecamatan Kebonsari, Kabupaten Madiun. Jurnal Ilmiah Pendidikan, 2(2), 167-173

Sumargi, A., Sofronoff, K. \& Morawska, A. (2015). Understanding Parenting Practices and Parents Views of Parenting Programs: A survey Among Indonesian Parents Residing in Indonesia and Australia. Journal of Child and Family Studies, 24(1). 141-160. doi:10.1007/s10826-013-9821-3

Umargi, A., Sofronoff, K. \& Morawska, A. (2015). A Randomized- Controlled Trial of the Triple P-Positive Parenting Program Seminar Series with Indonesian Parents. Child Psychiatry $\mathcal{E}$ Human Development. 46, Issue 4.pp 749761.

Tavassolie, T., Dudding, S., Madigan, A, L., Thorvardarson, E., Winsler, A. (2016). Differences in Perceived Parenting Style Between Mothers and Fathers: Impication for Child Outcome and Marital Conflict. J Child Fam Stud, 25, 2055-2068

Turner, Erlanger, A., Chandler, Megan., \& Heffer, Robert, W. (2009). The Influence 
of Parenting Styles, Achievement Motivation, and Self efficacy On Academic Performance in College Students. Journal of College Student Development, 50(3), pp. 337-346

Unayah, N \& Sabarisman, M. (2015). Fenomena Kenakalan Remaja dan Kriminalitas. Jurnal Sosio Informa, 1 (2), 121-140.
Unnever, J.D., Cullen, F.T., \& Agnew, R. (2006). Why is "Bad" Parenting Criminogenic?, Implications From Rival Theories. Youth Violence and Juvenile Justice, 4 (1), 3-33: DOI: $10.1177 / 1541204005282310$

Yus, A. (2015). didikan Anak Usia Dini. Jakarta: Prenada Media Group. 